\title{
The Importance of Circular Economy (CE) and its Effect on the Plastic Packaging Supply Market
}

\section{A körforgásos gazdaság jelentősége és hatása a múanyag csomagolóanyag ellátási piacára}

There is an increasing pressure from the public, governments and the industry itself to move towards to a more sustainable world. In 2015 the European Commission launched its action plan for the circular economy (CE), followed by several further legislation and regulation worldwide, sustainability commitments of FMCG and manufacturing companies, retailers, and foundations. The transition from current linear economy to circular economy requires new actions and policies, and impose extra challenges on all participants on the market. Sustainability, especially in relation with plastics, needs to be examined in its entirety. Beyond legislation, this study is investigating how the big players on the market have been influenced by CE, which sustainable goals they target to reach and by when, and whether these targets are aligned with CE. The study also analyses strategy approach and the effect on the organisations' sourcing activities.

JEL classification: Q5, Y9

Keywords: Circular economy, plastic packaging, procurement, FMCG

Egy fenntarthatóbb világ megvalósításának igénye egyre szélesebb körben jelenik meg, érintve a kormányzatokat, a lakosságot és a különböző iparág szereplőit is. 2015-ben az Európai Bizottság megjelentette a körforgásos gazdaságra vonatkozó uniós cselekvési tervét, amelyet további jogszabályok és szabályozások követtek világszerte. Ennek hatására az FMCG-szektor és számos gyártó vállalat, a kiskereskedők és az alapítványok is elkezdtek fenntarthatósággal kapcsolatos kötelezettségvállalásokat tenni. A jelenlegi lineáris gazdaság átformálása körforgásos gazdaságba új intézkedéseket és irányelveket tesz szükségessé, ami új kihívást jelent a piac összes szereplője számára. A fenntarthatósági kérdéseket, különösen a müanyagokkal

Katalin Erdei-Derschner is a PhD student at the University of Public Service Doctoral School of Public Administration Sciences. E-mail: erdei.derschner@gmail.com 


\begin{abstract}
kapcsolatosokat, teljes egészében, minden részletre kiterjedően kell elemezni. A jogszabályi kereteken túlmenöen a tanulmány vizsgálja, hogy a körforgásos gazdaság milyen befolyással van a piac legjelentősebb szereplöire, ennek hatására milyen fenntarthatósági célkitüzéseket fogalmaztak meg, és hogy ezek mennyire vannak összhangban a körforgásos gazdaság általános törekvéseivel. A tanulmány végül azt vizsgálja, hogy a fenntarthatósági célkitüzések megjelennek-e a vállalatok beszerzési stratégiáiban.
\end{abstract}

JEL-klasszifikáció: Q5, Y9

Kulcsszavak: körforgásos gazdaság, müanyag csomagolás, beszerzés, FMCG

\title{
1. Introduction: Why plastic matters?
}

Based on the latest calculation, 359 million tonnes of plastic is produced worldwide annually, but only a small share of it is recycled or reused, the rest goes to landfill or marine littering. ${ }^{1}$ Research estimates that there are over 150 million tonnes of plastic in the ocean today, overall 95 per cent of that (in weight) are plastic packaging material. ${ }^{2}$ Only 14 per cent of plastic packaging waste is collected for recycling and only 5 per cent is reused after sorting. ${ }^{3}$ In a business-as-usual scenario, the ocean is expected to contain 1 tonne of plastic for every 3 tonnes of fish by 2025, and more plastics than fish (by weight) by 2050. ${ }^{4}$ Over 90 per cent of the global plastic need is covered from fossil based, virgin material. The majority of plastic leaked into the environment comes from Asia where waste infrastructure systems are much less developed than in countries like Germany or the U.S. Globally, 82 per cent of the total plastic production is leaking into the ocean in Asia, while this figure in the U.S. and Europe is around 2 per cent. ${ }^{5}$

Basically, plastic was invented as a long-lasting, life-extending material with a multitude of useful applications. Today, plastic is the world's most popular packaging solution: nearly 52 per cent of global consumer packaging is made out of plastic (33 per cent flexible and 19 per cent rigid), while only 5 per cent out of paper. ${ }^{6}$ Plastic waste is one of many types of waste that takes too long to decompose. Normally, plastic items can take up to 1,000 years to decompose in landfills. Even plastic bags, what we use in our everyday life, take anywhere from 10 to 1,000 years to decompose, and plastic bottles can take 450 years or more. ${ }^{7}$

All of these put the plastic industry in a difficult situation. There is low circularity of plastics, less than 10 per cent of the total volume produced is suitable for circular approach. ${ }^{8}$ Environmental contamination is very high due to the high ratio of single-use

\footnotetext{
'Plastics - The facts 2019', Plastics Europe, 2019, 14.

The New Plastics Economy. Rethinking the Future of Plastics, Ellen MacArthur Foundation, 2016, 29.

The New Plastics Economy, 26.

The New Plastics Economy, 17.

The New Plastics Economy, 38.

Jukka Moisio, 'Sustainability - A food packaging converter's view'. Huhtamaki, September 26, $2018,9$.

Rick Leblanck, 'The Decomposition of Waste in Landfills', The balance-small business, 2019, 1.

The New Plastics Economy, 12.
} 
plastic and the micro plastics proliferation. The plastic waste collection is asymmetric. There are regions (especially in Europe), where collection and sorting happen at a high rate, but most of the countries in other regions are more backward. The biggest portion of plastic waste still goes to landfill, more than 1.5 billion euro investment would be needed annually to build up an appropriate size recycling capacity. ${ }^{9}$ Currently there is a limited number of products which are produced from recycled plastic, although there are more and more initiatives in this direction, like Ikea's removal\&recycling furniture service, where they take care of old furniture by disposing it in a sustainable and environmentally friendly way; or that plastic rubbish bags are now generally made only from recycled plastic resin. Despite all these initiatives, the actual application base is still very low, and the economical scale of raw materials is also currently too low, while the cost of possible sustainable alternatives is too high. ${ }^{10}$

Public pressure is increasing further to take actions (for example World Cleanup Day) by activists (like Greta Thunberg) and publications such as Greenpeace's publication of 'These 10 companies are flooding the planet with throwaway plastic'. ${ }^{11}$

Governments are also introducing new legislation to help make plastic consumption more sustainable. With China (previously the world's largest importer of plastic waste in the world) no longer accepts the import of certain types of plastics as of 2017, western countries need to deal with their plastic differently, leading to even bolder targets and regulations.

To effectively change this complex system, one requires heavy investments from the players on the market, to generate innovation and new knowledge, as well as a change in the mindsets.

This study has three purposes:

- First to determine if commitments and sustainability goals, targets, established by companies in the FMCG sector follow the main directions set out by the Circular Economy and New Plastic Economy. (P1)

- The second aim of the study is to determine whether companies only make bold statements on $\mathrm{CE}$, or they are genuinely embedding these into their strategies. There is a clear expectation towards big companies to act in socially and environmentally responsible ways. Positive communication in this field has a high potential of advertising value and it can even help gain market share. However, making only statements is not enough, they need to take real action and put strategies behind, which they should follow through to implementation. The investigation was done based on two parameters: the existence of a regularly reviewed sustainability report, and the measurable targets / KPI-s in it. (P2)

- Finally, the study tries to determine if the companies' sourcing activities are also in line with the challenges of $\mathrm{CE}$, and if they are developed towards sustainable procurement. (P3)

'Global Commitment. A circular economy for plastic in which it never becomes waste', Ellen MacArthur Foundation, 2018.

10 Kevin Longworth, 'Plastics and the Sustainable Future: Opportunities and Challenges', Conference paper, FPE Conference, Barcelona, 2018.

11 Ryan Schleeter, 'These 10 companies are flooding the planet with throwaway plastic', GreenPeace, October 9, 2018, 1 . 


\section{The Circular Economy}

The history of CE is going back to the 1970s, when Stahel and Reday-Mulvey ${ }^{12}$ described a vision of an economy in terms of loops and its impact on job creation and competitiveness. In the late 1980s, other authors like Frosch ${ }^{13}$ and Gallopoulos, ${ }^{14}$ initiated a discussion on the importance of closing material loops in industrial processes. The Ellen MacArthur Foundation is one of the organisations that contributed the most to spreading the concept of CE. ${ }^{15}$

The Ellen MacArthur Foundation defines a circular economy as an industrial system that aims to remove waste through the design of materials and products that support recycling. Its principles are to minimise the generation of waste and all types of pollution, to keep products and materials in use and to regenerate natural systems. Instead of the 'end of life cycle' concept, it supports recovery and recycling, encourages the use of renewable energy by all actors in the economy, and eliminates the use of toxic chemicals that hinder reuse.

While the Ellen MacArthur Foundation describes the circular economy as an 'industrial system that is restorative or regenerative by intention and design', the European Action Plan states that circular economy is an economy 'where the value of products, materials and resources is maintained in the economy for as long as possible, and the generation of waste minimized'. At the bottom of the European Union's 2015 action plan, the circular economy is defined as a system 'in which the value of products, raw materials and resources is preserved on the economy for as long as possible and the generation of waste is kept to a minimum' ${ }^{16}$

Circular economy makes a significant contribution to the EU's efforts to create a sustainable, low-carbon, resource-efficient and competitive economy by creating new and sustainable competitive advantages, supporting the development of innovative, more efficient ways of producing, consuming, and increasing employment. ${ }^{17}$ With the advent of the concept of the $\mathrm{CE}$, the concept of circular procurement also appeared. Circular procurement is an environmental-friendly procurement approach, that recognises the supporting role of big companies (and also public organisations) in the transition to the circular economy. Circular Procurement supports all EU and Member State efforts described above to create a sustainable, low-carbon, resource-efficient and competitive economy by creating new and sustainable competitive advantages, supporting

12 Walter R Stahel and Geneviève Reday-Mulvey, 1977 the potential for substituting manpower for energy, report to the Commission of the European Communities. Brussels, 1977.

13 Robert A Frosch, The Industrial Green Game: Implications for Environmental Design and Management (Washington: National Academy of Engineering, 1997), 37-47.

14 Robert A Frosch and Nicholas E Gallopoulos, 'Strategies for Manufacturing', Scientific American 261, no 3 (1989), 152.

15 Frosch, The Industrial Green Game, 37-47; Laura Talens Peiro, Davide Polverini, Fulvio Ardente and Fabrice Mathieux, 'Advances towards circular economy policies in the EU: The new Ecodesign regulation of enterprise servers', Resources, Conservation and Recycling 154 (2020), 154; 'Towards the Circular Economy', Founding Partners of the Ellen MacArthur Foundtation, 2013, 8.

16 Closing the loop - An EU action plan for the Circular Economy. European Commission, COM(2015) 614 final, 2015.

17 Closing the loop, 1. 
the development of innovative, more efficient ways of producing and consuming, and increasing pressure from public, regulators and the industry side also.

\section{Key drivers of the plastic industries}

The regulatory pressure which has also been rising in the last few years has finally been converted into actions. In 2019, 3 years after its adoption, the European Union announced the fulfilment of its 54-point circular economy action plan. ${ }^{18}$ This plan includes 54 forward-looking measures covering the whole life cycle of products, from production to consumption and waste management to the market for secondary raw materials. It also identifies five priority areas in the value chain where the transition needs to be accelerated: plastics, food waste, critical raw materials, construction and demolition work, biomass and bio-based materials. The action plan places great emphasis on ensuring that the new economic framework conditions provide the necessary incentives for investment and innovation. The aim of this action plan is to help accelerate the transition to a circular economy, increase global competitiveness and sustainable economic growth, and create new jobs in Europe. ${ }^{19}$

As such, all participants of the supply chain should recognise the importance of circular economy and look for ways to apply circular economy principles in their businesses.

There are several key factors that drive the circular economy for plastics in the European Union:

- European Green Deal ${ }^{20}$

- 2018 EU Plastics Strategy ${ }^{21}$

- EU Circular Economy Package ${ }^{22}$

- Packaging and Packaging Waste Directive, which sets a plastics packaging recycling target of 55 per cent by 2030, which may include an element of reuse ${ }^{23}$

- 2019 EU Single Use Plastic Products Directive ${ }^{24}$

- Ecodesign Directive, that has been identified as one of the most suitable legislative tools for achieving some of the objectives in the package, since it has the potential to translate the circular economy principles into specific product material efficiency requirements ${ }^{25}$

On country level there are several further local rules and/or recommendations which drive evolution towards CE. In the UK, the UK Plastic Ban targets the elimination of all avoidable plastic waste by 2042 and also proposes a tax of plastic packaging that does not

\footnotetext{
EU Circular Economy Action Plan. European Commission, 2020.

Towards Circular Economy. European Commission, 2019, 1.

A European Green Deal 2019-2025. European Commission, 2019.

EU Plastics Strategy. European Commission, 2018,

A new Circular Economy Action Plan. European Commission, 2020.

Packaging and Packaging Waste. European Commission, 2019.

Directive (EU) 2019/904 of the European Parliament and of the Council.

Ecodesign. European Commission, 2020.
} 
contain at least 30 per cent recycled plastic as of April 2022. ${ }^{26}$ In France, Plastic cutlery will begin to be banned from 2020. ${ }^{27}$ Taiwan and the Isole Trimiti region (Italy) are also introducing Single-use Plastic Ban. China set up the Plastic Import Ban, prohibiting the import of selectively recycled plastics in order to focus on the collection and recycling of domestic waste and high-quality plastic waste. ${ }^{28}$ Another big push to the plastic industry was The German Packaging Act (effective January 1, 2019), which states that the plastic brands will need to declare the total amount of packaging they release into the consumer market or will face fines of up to $€ 200,000$. $^{29}$

Achieving the systemic change needed to shift the global plastic value chain will require major collaboration efforts between all stakeholders across the global plastics value chain - consumer goods companies, plastic packaging producers and plastics manufacturers, businesses involved in the collection, sorting and reprocessing, local authorities, policy-makers and NGOs.

For retailers, brand owners and consumers, circular economy has been driven by the World Economic Forum and the New Plastic Economy. Companies should work towards using 100 per cent reusable, recyclable or compostable packaging by 2030 and be prepared for new demands generated by the evolving consumer consciousness concerning waste and recycling. The above mentioned Ellen MacArthur Foundation ('the Foundation') and New Plastic Economy has been rallying businesses and governments behind this positive vision of a circular economy for plastic. In January 2018, 11 leading companies committed to work towards 100 per cent reusable, recyclable, or compostable plastic packaging by 2025. A network of national New Plastics Economy implementation initiatives aligned around a common vision and set out ambitious targets. The first Plastics Pact has been launched in the U.K., implemented by the U.K. charity WRAP. The New Plastic Economy Global Commitment is line in the sand in the fight against plastic waste and pollution. It united 285 entities (businesses, governments, NGO, universities, and other organisations from around) already in 2018, and up to 400 by 2019 who signed the document.

Vision of the commitment is:

- elimination of problematic or unnecessary plastic packaging through redesign, innovation, and new delivery models is a priority

- reuse models are applied where relevant, reducing the need for single-use packaging

- all plastic packaging is 100 per cent reusable, recyclable, or compostable

- all plastic packaging is reused, recycled, or composted in practice

- the use of plastic is fully decoupled from the consumption of finite resources

- all plastic packaging is free of hazardous chemicals, and the health, safety and rights of all people involved are respected ${ }^{30}$

'Single use plastic', Gov.uk, 2019.

Axel Barrett, 'Summary of Plastic Bans in France', Bioplastic News, December 28, 2019, 1.

Amy L Brooks, Shunli Wang and Jenna R Jambeck, 'The Chinese import ban and its impact on global plastic waste trade', Science Advances 4, no 6 (2018).

29 Taylor Wessing, 'German Packaging Act 2019 for Producers \& Retailers: Without registration no commercialization!' Lexology, December 27, 2018, 1.

30

The New Plastics Economy. 
By today it is clear that plastic should not be the biggest enemy. There are several pieces of evidence which add significant value to the flexible materials sustainability benefits throughout the entire life cycle of a package, when compared to other package formats.

These advantages are:

- material/resource efficiency

- lightweight/source reduction

- transportation benefits due to inbound format and lightweight nature

- extended shelf life

- reduced volume of materials going to landfill

- high product-to-package ratio

- beneficial life cycle metrics (carbon impact, fossil fuel used, water consumption) ${ }^{31}$

Despite a number of sustainability benefits, the challenges for flexible and rigid packaging still remain critical. The key challenges lie in the material collection and recycling, the mixed plastic stream, the high content of organic and other waste, and that the alternative material must not result in reduction of shelf-life or higher weight, as the losses would be far greater than the benefits. Finally, due to their cost implication, these points can cause delays in their funding and implementation. Last but not least, sustainable solutions are considered to be more expensive than linear version. As Martin R Stuchtey stated:

- Plastics are the workhorse material of the modern economy - with unbeaten properties. However, they are also the ultimate single-use material. Growing volumes of end-of-use plastics are generating costs and destroying value to the industry. After-use plastics could - with circular economy thinking - be turned into valuable feedstock. Our research confirms that applying those circular principles could spark a major wave of innovation with benefits for the entire supply chain. ${ }^{32}$

Due to all the above mentioned pressure, more and more commitments are created across the entire supply chain, starting from raw material production through converters, supermarket chains, brand owners and logistic companies. The change is not easy at all, and besides, effecting each and every step of the entire product life cycle requires a change of mindset from all participants, including end-users and costumers as well.

\section{Findings}

The study narrows down the scope to the FMCG sector, analysing what effects CE has; how selected companies are adapting plastic related sustainability requirements; how they are formulating their goals, setting up targets to contribute to environmentally conscious economic growth; and if these activities are materialising in their procurement

\footnotetext{
31 Todd Bukowski and Michael Richmond, 'A Holistic View of the Role of Flexible Packaging in a Sustainable World', Prepared for the Flexible Packaging Association, April 9, 2018, 13. 
activities. The main focus of the research is the plastic related commitments. During our data collection other commitments regarding energy, $\mathrm{CO}_{2}$ emission reduction, and so on, were also tracked but are not discussed as part of this study.

The study is based on content analysis, primary qualitative data collected from data and databases available on the Internet. Data presented in this study were collected mainly from the relevant companies' homepage and press releases. To collect relevant data, the listed companies' officially published announcements, annual and sustainable reports, and press releases were checked. The selected 'top 20 group' of companies are defined by net revenue from 2017, based on CG official list, containing only publicly traded companies. ${ }^{33}$

After creating the list and ranking of the companies, they were grouped by relevant sectors, focusing on their main activity (biggest share in the net income). As a result, 6 groups have been outlined: Food and Beverage (8), Household Goods (1), Tobacco (3), Drinks (alcoholic) (2), Health \& Beauty Aids (3), Apparel/Footwear/Accessories and so on (3).

Seven companies out of the twenty signed the New Public Economy, which is considered as the clearest sign to be committed to CE. Further 2 companies signed CE100, ${ }^{34}$ which ultimately results in around 50-50 per cent share within the committed and non-committed companies towards CE. It also became apparent which sectors are less engaged: from the selected list neither of the companies from the Tobacco, Apparel/ Footwear/Accessories and the Drinks sector signed the commitment. The biggest coverage is discernible in the Health \& Beauty Aids group, where two third of the companies signed the commitment, and additionally, $P \& G$ also announced their Ambition 2030 sustainability goals in April 2018, which includes several strong global goals for packaging, including 100 per cent recyclable or reusable packaging by 2030 .

To sum up the findings, all commitments point in the same direction marking the same route, regardless of the fact whether they signed the New Plastic Economy Commitment or not. There are four main routes defined by the $\mathrm{CE}$ commitments and followed by the FMCG sector. First is the reduction of packaging material in terms of size, weight and thickness, towards taking action to eliminate problematic or unnecessary plastic. Second is to increase recyclability, reusability or compostability of packaging materials - mostly towards 100 per cent, or in 2 steps: 50 per cent by 2025 and 100 per cent by 2030. The third commitment type is the increased use of recycled plastic in packaging materials. There is a wide range in the definitions, from only impacting 1 particular product or product brand up to 100 per cent depending on the specific material. Last but not least, the smallest portion of the commitments are about design for recyclability and education of customers on proper waste management.

Even those companies who are not engaged by the Ellen MacArthur Foundation make strong commitments, with clear goals and deadlines, targeting that 100 per cent of their plastic packaging be reusable, recyclable, or compostable. The most widely undertaken commitment is to make 100 per cent of plastic packaging reusable, recyclable, or

'Top 100 Consumer Goods Companies of 2018', CGT, 2018.

The CE100 is a collaborative network of businesses, innovators, cities and governments, universities and thought leaders who work together to accelerate adoption of circular economy practices and processes that maximise the use of resources. 
compostable within an exact time frame. 70 per cent of the sample made statements on this target. Composability is of less interest in the sample range, they are rather looking for plastic with recycled content between 15-50 per cent, and the majority of them with 25 per cent by 2025 .

Table 1

TOP 20 FMCG company ranking, grouping and commitments

\begin{tabular}{|c|c|c|c|c|c|c|c|}
\hline 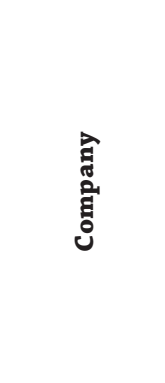 & 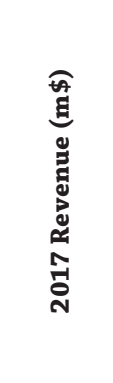 & 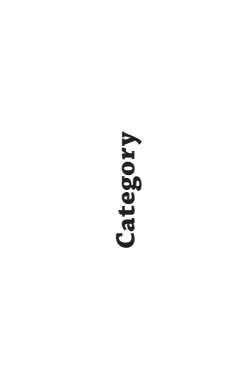 & 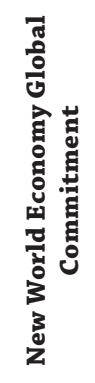 & 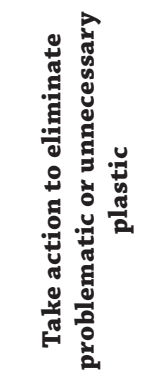 & 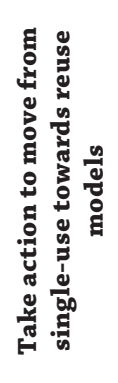 & 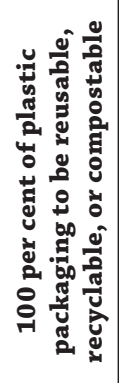 & 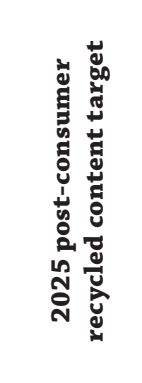 \\
\hline Nestlé S.A. ${ }^{35}$ & $\$ 89,139$ & Food, Beverage & signed & by 2025 & by 2025 & by 2025 & 15 per cent \\
\hline $\mathrm{PMI}^{36}$ & $\$ 78,098$ & Tobacco & $\begin{array}{c}\text { not } \\
\text { signed }\end{array}$ & & & by 2025 & \\
\hline $\begin{array}{l}\text { Procter \& } \\
\text { Gamble }^{37} \\
\end{array}$ & $\$ 65,058$ & $\begin{array}{l}\text { Health \& Beauty } \\
\text { Aids ( } 58 \text { per cent) }\end{array}$ & $\begin{array}{c}\text { not } \\
\text { signed }\end{array}$ & $\begin{array}{c}\text { compostable } \\
\text { by } 2025\end{array}$ & & by 2030 & \\
\hline $\mathrm{PepsiCo}^{38}$ & $\$ 63,525$ & Food, Beverage & signed & by 2025 & by 2025 & by 2025 & 25 per cent \\
\hline $\begin{array}{l}\text { Unilever } \\
\text { N.V. }{ }^{39}\end{array}$ & $\$ 60,628$ & $\begin{array}{l}\text { Health } \& \text { Beauty } \\
\text { Aids ( } 40 \text { per cent) }\end{array}$ & signed & by 2025 & by 2025 & by 2025 & 25 per cent \\
\hline $\mathrm{AB} \operatorname{InBev}{ }^{40}$ & $\$ 56,444$ & Drinks & $\begin{array}{c}\text { not } \\
\text { signed }\end{array}$ & & & by 2025 & \\
\hline $\begin{array}{l}\text { Christian } \\
\text { Dior }\end{array}$ & $\$ 49,287$ & $\begin{array}{c}\text { Apparel/Footwear/ } \\
\text { Accessories }\end{array}$ & $\begin{array}{c}\text { not } \\
\text { signed }\end{array}$ & & & by 2024 & \\
\hline $\mathrm{LVMH}^{41}$ & $\$ 48,122$ & $\begin{array}{c}\text { Apparel/Footwear/ } \\
\text { Accessories }\end{array}$ & $\begin{array}{c}\text { not } \\
\text { signed }\end{array}$ & & & & \\
\hline JBS USA $^{42}$ & $\$ 43,132$ & Food, Beverage & $\begin{array}{c}\text { not } \\
\text { signed }\end{array}$ & & & & \\
\hline Tyson Foods & $\$ 38,260$ & Food, Beverage & $\begin{array}{c}\text { not } \\
\text { signed }\end{array}$ & & & & \\
\hline
\end{tabular}

'What is Nestlé doing to tackle plastic packaging waste?' Nestlé, 2020.

'Sustainibility report', PMI, 2018.

'P\&G announces new global commitment to reduce plastic', P\&G, 2019.

'Packaging', PEPSICO, 2020.

'Rethinking plastic packaging', Unilever, 2020.

'Circular Packaging', AB Inbev, 2020.

'Environmental Commitment', Louis Vuitton, 2020.

'Waste reduction and recycling', JBS USA, 2020. 


\begin{tabular}{|c|c|c|c|c|c|c|c|}
\hline 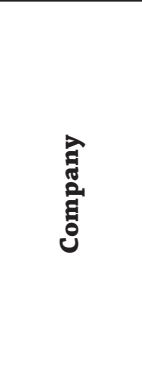 & 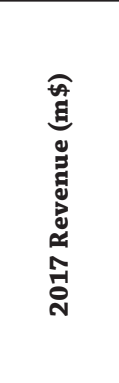 & 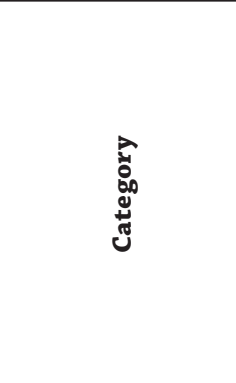 & 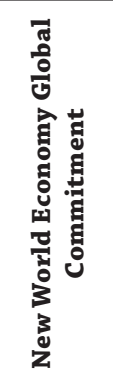 & 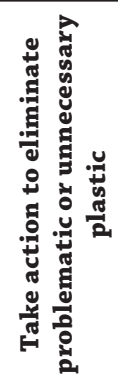 & 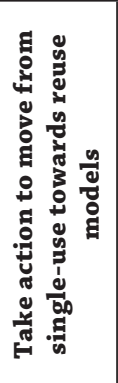 & 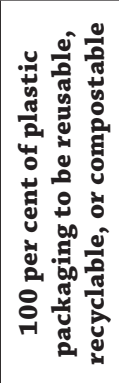 & 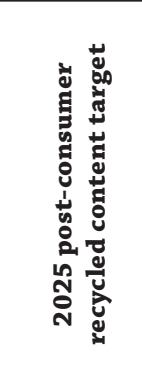 \\
\hline $\begin{array}{c}\text { Coca-Cola } \\
\text { Co. }^{43}\end{array}$ & $\$ 35,410$ & Food, Beverage & signed & by 2025 & by 2025 & by 2025 & $\begin{array}{c}50 \text { per cent } \\
\text { by } 2030, \\
\text { Western } \\
\text { European } \\
\text { business by } \\
2025\end{array}$ \\
\hline Nike Inc. ${ }^{44}$ & $\$ 34,350$ & $\begin{array}{c}\text { Apparel/Footwear/ } \\
\text { Accessories }\end{array}$ & $\begin{array}{c}\text { not } \\
\text { signed }\end{array}$ & & & $\begin{array}{c}\text { Project } \\
\text { base }\end{array}$ & \\
\hline $\begin{array}{c}\text { Imperial } \\
\text { Brands, } \\
\text { PLC }^{45}\end{array}$ & $\$ 34,140$ & Tobacco & $\begin{array}{l}\text { not } \\
\text { signed }\end{array}$ & & & & \\
\hline $3 \mathrm{M} \mathrm{Co} .{ }^{46}$ & $\$ 31,657$ & Household Goods & $\begin{array}{l}\text { not sig- } \\
\text { ned, but } \\
\text { CE100 }\end{array}$ & & & by 2025 & \\
\hline L'Oréal"47 & $\$ 29,381$ & $\begin{array}{c}\text { Health \& Beauty } \\
\text { Aids }\end{array}$ & Signed & by 2025 & by 2025 & by 2025 & $\begin{array}{c}30 \text { per cent } \\
\text { by } 2025\end{array}$ \\
\hline Danone $^{48}$ & $\$ 27,863$ & Food, Beverage & Signed & by 2025 & by 2025 & by 2025 & 25 per cent \\
\hline $\begin{array}{l}\text { Kraft } \\
\text { Heinz }^{49}\end{array}$ & $\$ 26,232$ & Food, Beverage & $\begin{array}{c}\text { not } \\
\text { signed }\end{array}$ & & & by 2025 & \\
\hline $\begin{array}{l}\text { Mondelez } \\
\text { Int. }{ }^{50}\end{array}$ & $\$ 25,896$ & Food, Beverage & Signed & by 2025 & by 2025 & by 2025 & 5 per cent \\
\hline $\begin{array}{l}\text { Altria } \\
\text { Group }^{51} \\
\end{array}$ & $\$ 25,576$ & Tobacco & $\begin{array}{c}\text { not } \\
\text { signed }\end{array}$ & & & & \\
\hline $\begin{array}{c}\text { Heineken } \\
\text { Holding } \\
\text { N.V. }\end{array}$ & $\$ 24,717$ & Drinks & $\begin{array}{l}\text { not sig- } \\
\text { ned, but } \\
\text { CE100 }\end{array}$ & & & & \\
\hline
\end{tabular}

Source: edited by the author based on the relevant webpages of the companies

43 'Sustainable Packaging', The Coca Cola Company, 2020.

44 'Move to zero', Nike, 2020.

45 'Reducing our environmental impact', Imperial Brands, 2020.

46 'Global Manufacturer 3M Joins Ellen MacArthur Foundation's CE100 Circular Economy Network', 3M, 2019.

$47 \quad$ 'Plastic Packaging Policy', L'Oreal, 2019.

48 'Circular Economy of Packaging', Danone, 2020.

49 'Kraft Heinz Expands Environmental Commitments to Include Sustainable Packaging and Carbon Reduction', Kraft Heinz, 2019.

50 'Mondelēz International Affirms Commitment to Sustainability 2020 and Climate Change Goals', Mondelēz, 2020.

51 'Environmental management', Altria, 2020.

52 'Our sustainability story', Heineken, 2020. 
Proposal one (P1) is confirmed based on the collected data, in case of those companies where commitments exists, sustainability goals, targets follow the main four directions set by the Circular Economy and New Plastic Economy. Results shows that 13 companies, out of the examined 20, have at least one focus is in CE direction.

In the second step, companies were examined how seriously they are dedicated to their commitments. Two aspects were evaluated during the data mining. First, if yearly sustainable report is available on the homepage with information about sustainability related commitments. The second topic investigated was, if CE or sustainability-related goals and milestones are defined; if any progress is measured against them, and whether it is clearly communicated on the homepage.

Findings shows that nearly all of the examined companies issue their sustainability reports on a yearly base: eighteen companies' reports were found online (no older than 2018). Content of the reports can vary; but common structural points can be identified. In case of fourteen companies (70 per cent) the goals and/or target figures were also clearly communicated, and even progress against the desired target value were measured.

Table 2

Strategic communication of the commitments and link to sourcing activity

\begin{tabular}{|c|c|c|c|c|c|c|c|c|c|c|c|c|c|c|c|c|c|c|c|c|c|}
\hline $\begin{array}{c}\text { Company/ } \\
\text { Communication }\end{array}$ & 惫 & $\sum_{\mathbf{Q}}$ & 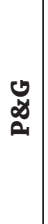 & 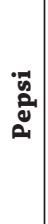 & $\begin{array}{l}\stackrel{\mathrm{d}}{\mathrm{d}} \\
\stackrel{\mathrm{z}}{\mathrm{g}} \\
\mathrm{g}\end{array}$ & 总 & 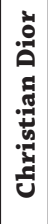 & 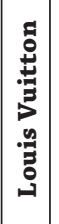 & 㽞 & 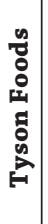 & 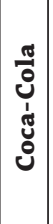 & 竞 & 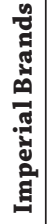 & $\sum_{m}^{\dot{S}}$ & 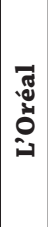 & 气̆ & 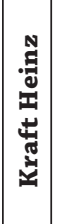 & 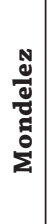 & 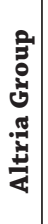 & 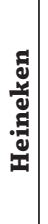 & 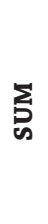 \\
\hline $\begin{array}{c}\text { Sustainable } \\
\text { report available }\end{array}$ & $\mathrm{Y}$ & $\mathrm{Y}$ & $\mathrm{Y}$ & $\mathrm{Y}$ & $\mathrm{Y}$ & $\mathrm{Y}$ & $\mathrm{Y}$ & & $\mathrm{Y}$ & $\mathrm{Y}$ & $Y$ & & $\mathrm{Y}$ & $\mathrm{Y}$ & $\mathrm{Y}$ & $\mathrm{Y}$ & $\mathrm{Y}$ & $\mathrm{Y}$ & $\mathrm{Y}$ & $\mathrm{Y}$ & 18 \\
\hline $\begin{array}{l}\text { Goals defined/ } \\
\text { clear milestones } \\
\text { communicated }\end{array}$ & $\mathrm{Y}$ & $\mathrm{Y}$ & $\mathrm{Y}$ & $\mathrm{Y}$ & $\mathrm{Y}$ & & & $\mathrm{Y}$ & $\mathrm{Y}$ & & $Y$ & $\mathrm{Y}$ & $\mathrm{Y}$ & $\mathrm{Y}$ & & $Y$ & & $\mathrm{Y}$ & & $\mathrm{Y}$ & 14 \\
\hline $\begin{array}{l}\text { Sustainable } \\
\text { sourcing }\end{array}$ & $\mathrm{Y}$ & & $\mathrm{Y}$ & $\mathrm{Y}$ & $\mathrm{Y}$ & $\mathrm{Y}$ & & & & & $Y$ & $\mathrm{Y}$ & $\mathrm{Y}$ & $\mathrm{Y}$ & $\mathrm{Y}$ & $\mathrm{Y}$ & & $\mathrm{Y}$ & $\mathrm{Y}$ & $\mathrm{Y}$ & 14 \\
\hline
\end{tabular}

* only social Responsibility Report, limitedly covering topics on sustainability Source: edited by the author based on the relevant webpages of the companies

Proposal two (P2) is disproved by the findings collected from relevant pieces of communication. Companies not only make bold commitments to move forward in the direction of $C E$, but the topic is handled strategically. Most of the investigated companies do have defined goals and targets, and progress are measured regularly (at least annually). Apparel/Footwear/Accessories and Tobacco sector appear to be the least developed in this sense.

Finally, the effect on sourcing activities have been evaluated (P3). Most of the dissertations regarding circular economy describe the technical difficulties of the implementation process, the enablers and development options in the first place. While procurement is neglected in this topic, this field has a clear supporting role in the effective change implementation and in reaching the set targets. CE is affecting the whole supply chain, 
including the entire supplier base (not just tier one suppliers, but the entire chain down to the primary source), product availability, performance and strategy. Also effective information flow must be secured during the development and change procedures. Sustainable sourcing is one of the key element of the circular procurement, covering not only $C E$ related sourcing activities, but several further aspects, like social, ethical and environmental performance factors, and can drive sustainability related developments alike. Sustainable procurement meets their entities needs for goods, services, utilities and works not on a private cost-benefit analysis, but with a view of maximising net benefits for themselves and the wider world. ${ }^{53}$

During this study we could only identify traces of data on whether sustainable sourcing is an existing practise at the investigated companies. CE in relation with procurement is too new to be evaluated in terms of data availability. To be able to evaluate if sourcing activity is developed towards sustainable and CE procurement requirements, existence of sustainable sourcing guidelines was considered.

The availability of sustainably sourcing guidelines and/or information are linked to the commitment level of the company. Analysed data shows that sustainable procurement strategy is part of the company's strategy, with 70 per cent of the tested sample owning directives available on their homepages about sustainable sourcing.

The overall level of commitment of the TOP20 companies is also showing a positive picture. At least one out of the three scrutinised areas was detectable at each of the companies, and half of the companies presented all three examined aspects.

Martin Agyemang et alia found that the main driver of many enterprises in Pakistan's automotive industry is that they want to gain a market share and pursue higher profits through increased competitiveness and overall sales by embracing and adopting CE initiatives. ${ }^{54}$ As a supplemental study, this investigation proves, that despite companies may use $C E$ as a marketing tool to gain better margin, they show up real activities and take the lead to drive the change.

Michael Lieder and Amir Rashid came to the conclusion in their study examining the manufacturing sector that jointly all stakeholders are able to support the implementation of the concept of CE. Their framework described three major aspects of CE, which is waste and environment (to avoid and minimise environmental impacts), resource scarcity motivating regenerative use of resources, and economic benefits for industrial companies in order to sustain and increase profitability. ${ }^{55}$ These three aspects are in line with the recommendation of New Plastic Economy and the findings of this study.

53 Konstantinos I Vatalis, Odysseus G Manoliadis and Dimitrios G Mavridis, 'Project performance indicators as an innovative tool for identifying sustainability perspectives in green public procurement', Procedia Economics and Finance 1 (2012), 401.

54 Martin Agyemang, Simonov Kusi-Sarpong, Sharfuddin Ahmed Khan, Venkatesh Mani, Syed Tahaur Rehman, and Horsten Kusi-Sarpong, 'Drivers and barriers to circular economy implementation', Management Decision 57, no 4 (2019), 988.

55 Michael Lieder and Amir Rashid, 'Towards circular economy implementation: a comprehensive review in context of manufacturing industry', Journal of Cleaner Production 115 (2016), 36. 
Implementation of CE into the daily life is not easy. Yuliya Kalmykova et alia developed a Strategies Database to summarise the methods of CE implementation described in the literature. Overall forty-four, in terms of material sourcing twelve best practice implementation strategies has been identified by the research group, including: extraction of bio-chemicals, functional and high quality recycling, diversity and cross-sector linkages, Life Cycle Assessment, and material substitution. ${ }^{56}$

\section{Conclusion}

The development of alternatives for plastic packaging is challenging. The benefits of this type of packaging includes its weight, cost, transportability and lower $\mathrm{CO}_{2}$ emission during production compared to other packaging materials, like glass. Also the ability to extend the shelf life of food makes plastic currently unavoidable. The population of the word is expected to grow by 1 billion by 2033, reaching 8.7 billion. ${ }^{57}$ This amount of people cannot be fed without plastic packaging, so plastic matters, and we need to learn to live with it, and handle it in the right way. Therefore, the whole supply chain is highly effected by several actions and challenges, like how to change current packagings' structure, how to secure the appropriate recycled content and quality of materials, how to meet with compliance requirements and regulation. There is only a limited volume of recycling stream available, mostly based on mechanical recycling. Usage of biodegradable and bio based resin is also a possible solution, which is theoretically available for all participants, but limited availability of these materials and their high cost makes change difficult. Compostability can be also mentioned here, since for plastics it is still rather a theoretical solution, as it is available at an industrial scale, but not as a homesize solution.

Efforts on changing linear economy to circular economy are shaping our present and future. Transformation requires sizeable extra steps from everyone, including governments, companies and individuals. Circular economy requires the efficient use of resources, waste minimisation, long-term value retention, reduction of primary resources and closed loops of products, and materials taking into consideration environmental boundaries and socioeconomic benefits. Plastic packaging industry gets special attention in circular economy, where supply plays a key role in materialising change. FMCG can be a key sector to effectively drive the change towards shaping consumers' mindset.

As we are still at the beginning of the journey, several aspects need to be researched and evaluated. The entire subject of Circular Economy is recommended for more detailed studies, especially how it formulates companies' business strategies.

\footnotetext{
$56 \quad$ Yuliya Kalmykova, Madumita Sadagopan and Leonardo Rosado, 'Circular economy - From review of theories and practices to development of implementation tools', Resources, Conservation \& Recycling 135 (2018), 196-197.

57 'World population by continets, 1950-2100', KSH, 2019.
} 


\section{References}

Agyemang, Martin - Simonov Kusi-Sarpong - Sharfuddin Ahmed Khan - Venkatesh Mani - Syed Tahaur Rehman - Horsten Kusi-Sarpong: 'Drivers and barriers to circular economy implementation', Management Decision 57, no 4 (2019), 971-999. Online: http://doi.org.10.1108/MD-11-2018-1178

Barrett, Axel: 'Summary of Plastic Bans in France'. Bioplastic News, December 28, 2019. Online: https://bioplasticsnews.com/2019/12/28/summary-plastic-bans-france/

Brooks, Amy L - Shunli Wang - Jenna R Jambeck: 'The Chinese import ban and its impact on global plastic waste trade'. Science Advances 4, no 6 (2018). Online: http:// doi.org.10.1126/sciadv.aat0131t0131

Bukowski, Todd - Michael Richmond: 'A Holistic View of the Role of Flexible Packaging in a Sustainable World'. Prepared for the Flexible Packaging Association, April 9, 2018. Online: https://perfectpackaging.org/wp-content/uploads/2018/09/FPAHolistic-View-of-Sustainable-Packaging.pdf

'Circular Economy of Packaging'. Danone, 2020. Online: www.danone.com/impact/ planet/packaging-positive-circular-economy.html

'Circular Packaging'. AB Inbev, 2020. Online: www.ab-inbev.com/sustainability/2025-sustainability-goals/circular-pakaging.html

Danziger, Pamela: 'Adidas Challenges The Fashion Industry In Sustainability. Pledging Only Recycled Plastic By 2024'. Forbes, July 18, 2019. Online: www.forbes.com/ sites/pamdanziger/2019/07/18/adidas-challenges-the-fashion-industry-in-sustainability-pledging-only-recycled-plastic-by-2024/

'Environmental Commitment'. Louis Vuitton, 2020. Online: https://ca-i2f.louisvuitton. com/eng-ca/magazine/articles/louis-vuitton-environmental-commitment

'Environmental management'. Altria, 2020. Online: www.altria.com/en/responsibility/ environmental-management

'Global Commitment. A circular economy for plastic in which it never becomes waste'. Ellen MacArthur Foundation, 2018. Online: www.newplasticseconomy.org/projects/global-commitment

Frosch, Robert A: The Industrial Green Game: Implications for Environmental Design and Management. Washington: National Academy of Engineering, 1997.

Frosch, Robert A and Nicholas E Gallopoulos: 'Strategies for Manufacturing'. Scientific American 261, no 3 (1989), 144-153. Online: www.jstor.org/stable/24987406?seq=1

‘Global Manufacturer 3M Joins Ellen MacArthur Foundation's CE100 Circular Economy Network'.3M, 2019. Online: https://news.3m.com/English/press-releases/press-releases-details/2019/Global-Manufacturer-3M-Joins-Ellen-MacArthur-Foundations-CE100-Circular-Economy-Network/default.aspx

Kalmykova, Yuliya - Madumita Sadagopan - Leonardo Rosado: 'Circular economy - From review of theories and practices to development of implementation tools'. Resources, Conservation \& Recycling 135 (2018), 190-201. Online: http://doi.org. 10.1016/j.resconrec.2017.10.034 
'Kraft Heinz Expands Environmental Commitments to Include Sustainable Packaging and Carbon Reduction', Kraft Heinz, 2019. Online: https://news.kraftheinzcompany. com/press-releases-details/2018/Kraft-Heinz-Expands-Environmental-Commitments-to-Include-Sustainable-Packaging-and-Carbon-Reduction/default.aspx

Leblanck, Rick: 'The Decomposition of Waste in Landfills'. The balance - small business, 2019. Online: www.thebalancesmb.com/how-long-does-it-take-garbage-to-decompose-2878033

Lieder, Michael - Amir Rashid: 'Towards circular economy implementation: a comprehensive review in context of manufacturing industry'. Journal of Cleaner Production 115 (2016), 36-51. Online: https://doi.org/10.1016/j.jclepro.2015.12.042

Longworth, Kevin: 'Plastics and the Sustainable Future: Opportunities and Challenges'. Conference paper, FPE Conference, Barcelona, 2018.

Moisio, Jukka: 'Sustainability - A food packaging converter's view'. Huhtamaki, September 26, 2018. Online: www.huhtamaki.com/globalassets/global/investors/ reports-and-presentations/en/2018/huhtamaki-sustainability-presentation_handelsbanken-seminar-sep-26-2018.pdf

'Mondelēz International Affirms Commitment to Sustainability 2020 and Climate Change Goals'. Mondelēz, 2020. Online: https://ir.mondelezinternational.com/ news-releases/news-release-details/mondelez-international-affirms-commitment-sustainability-2020

'Move to zero'. Nike, 2020. Online: www.nike.com/hu/en/sustainability

'Our sustainability story'. Heineken, 2020. Online: www.theheinekencompany.com/

'P\&G announces new global commitment to reduce plastic'. P\&G, 2019. Online: www. pg.co.uk/blogs/Plastic50by2030/

'Packaging'. PEPSICO, 2020. Online: www.pepsico.com/sustainability/focus-areas/ packaging

Peiró, Laura Talens - Davide Polverini - Fulvio Ardente - Fabrice Mathieux: 'Advances towards circular economy policies in the EU: The new Ecodesign regulation of enterprise servers'. Resources, Conservation and Recycling 154 (2020). Online: http://doi. org/10.1016/j.resconrec.2019.104426

'Plastic Packaging Policy'. L'Oreal 2019. Online: www.loreal.com/en/articles/plastic-packaging-policy/

'Plastics - The facts 2019'. Plastics Europe, 2019. Online: www.plasticseurope.org/ application/files/9715/7129/9584/FINAL_web_version_Plastics_the_facts2019 _14102019.pdf

'Reducing our environmental impact'. Imperial Brands, 2020. Online: www.imperialbrandsplc.com/sustainability/approach/reducing-environmental-impact.html

'Rethinking plastic packaging'. Unilever, 2020. Online: www.unilever.com/sustainable-living/reducing-environmental-impact/waste-and-packaging/rethinking-plastic-packaging/

Schleeter, Ryan: 'These 10 companies are flooding the planet with throwaway plastic'. Greenpeace, October 9, 2018. Online: www.greenpeace.org/international/story/18876 /these-10-companies-are-flooding-the-planet-with-throwaway-plastic/

Európai Tükör 2020/4. 
'Single use plastic'. Gov.uk, 2019. Online: www.gov.uk/government/consultations/single-use-plastic-banning-the-distribution-andor-sale-of-plastic-straws-stirrers-andplastic-stemmed-cotton-buds-in-england

Stahel, Walter R and Geneviève Reday-Mulvey: 1977 the potential for substituting manpower for energy, report to the Commission of the European Communities. Brussels, 1977.

'Sustainable Packaging'. The Coca Cola Company, 2020. Online: www.coca-colacompany. com/sustainable-business/packaging-sustainability

'Sustainibility report'. PMI, 2018. Online: www.pmi.com/resources/docs/default-source/ pmi-sustainability/pmi-sustainability-report-2018-low-res.pdf

'Top 100 Consumer Goods Companies of 2018'. CGT, 2018. Online: https://consumergoods.com/top-100-consumer-goods-companies-2018

'Towards the Circular Economy'. Founding Partners of the Ellen MacArthur Foundtation, 2013.

The New Plastics Economy. Rethinking the Future of Plastics. Ellen MacArthur Foundation, 2016. Online: www.ellenmacarthurfoundation.org/assets/downloads/EllenMac ArthurFoundation_TheNewPlasticsEconomy_Pages.pdf

The New Plastics Economy. Rethinking the future of plastics. World Economic Forum, 2016. Online: www3.weforum.org/docs/WEF_The_New_Plastics_Economy.pdf

Vatalis, Konstantinos I - Odysseus G Manoliadis - Dimitrios G Mavridis: 'Project performance indicators as an innovative tool for identifying sustainability perspectives in green public procurement'. Procedia Economics and Finance 1 (2012), 401-410. Online: http://doi.org.10.1016/s2212-5671(12)00046-9

'Waste reduction and recycling'. JBS USA, 2020. Online: https://sustainability.jbssa. com/chapters/environment/waste-reduction-recycling/

Wessing, Taylor: 'German Packaging Act 2019 for Producers \& Retailers: Without registration no commercialization!' Lexology, December 27, 2018. Online: www. lexology.com/library/detail.aspx?g=f461e38d-0d2a-4fc7-8cad-b28492944385

'What is Nestlé doing to tackle plastic packaging waste?' Nestlé, 2020. Online: www.nestle. com/ask-nestle/environment/answers/tackling-packaging-waste-plastic-bottles

'World population by continets, 1950-2100'. KSH, 2019. Online: www.ksh.hu/interaktiv/grafikonok/vilag_nepessege_en.html

\section{Legal references}

A European Green Deal 2019-2025. European Commission, 2019. Online: https:// ec.europa.eu/info/strategy/priorities-2019-2024/european-green-deal_en

A new Circular Economy Action Plan. European Commission, 2020. Online: https://eur-lex. europa.eu/legal-content/EN/TXT/?qid=1583933814386\&uri=COM:2020:98:FIN

Closing the loop - An EU action plan for the Circular Economy. European Commission, $\operatorname{COM}(2015) 614$ final, 2015. Online: https://eur-lex.europa.eu/legal content/EN/ TXT/?uri=CELEX per cent3A52015DC0614

Directive (EU) 2019/904 of the European Parliament and of the Council. Online: https://eurlex.europa.eu/legal-content/EN/TXT/PDF/?uri=CELEX:32019L0904 
Ecodesign. European Commission, 2020. Online: https:/ec.europa.eu/growth/industry/ sustainability/ecodesign_en

EU Circular Economy Action Plan. European Commission, 2020. Online: https://ec.europa. eu/environment/circular-economy/

EU Plastics Strategy. European Commission, 2018. Online: https://ec.europa.eu/commission/news/eu-plastics-strategy-2018-nov-20_en

Packaging and Packaging Waste. European Commission, 2019. Online: https://ec.europa. eu/environment/waste/packaging/legis.htm

Towards Circular Economy. European Commission, 2019. Online: https://ec.europa.eu/commission/priorities/jobs-growth-and-investment/towards-circular-economy_hu 